Елена Круглова

Московский городской педагогический университет Филологический факультет

Кафедра русской литературы

elkruglova@list.ru
УДК 821.161.1.09"18"

https://doi.org/10.18485/slavistika.2020.24.2.27

оригинални научни рад

примљено 24.02.2020.

прихваћено за штампу 18.09.2020.

\title{
СИТУАЦИЯ ВСТРЕЧИ СО СМЕРТЬЮ: ПСИХОАНАЛИТИЧЕСКОЕ ПРОЧТЕНИЕ МИНИАТЮРЫ И.С. ТУРГЕНЕВА «НАСЕКОМОЕ»
}

Статья посвящена вопросам психоаналитической интерпретации темы смерти в миниатюре И.С. Тургенева «Насекомое». Рассматриваются ее психологические предпосылки и соотнесенность с такими явлениями, как сон и страх. Автор статьи приходит к выводу о том, что в тургеневской миниатюре представлен процесс преодоления страха смерти, а не приятие ее неизбежности.

Ключевые слова: Иван Тургенев, Стихотворения в прозе, смерть, страх, сновидение, психоанализ.

The article is based on the psychoanalytic interpretation of the theme of death in a miniature by I.S. Turgenev "The Insect". Its psychological prerequisites and correlation with such phenomena as sleep and fear are considered. The author of the article comes to the conclusion that Turgenev's miniature presents the process of overcoming the fear of death, and not the acceptance of its inevitability.

Keywords: Ivan Turgenev, poems in prose, death, fear, dream, psychoanalysis.

Стихотворение в прозе Ивана Сергеевича Тургенева «Насекомое» входит в цикл миниатюр, который автор называл вначале «Posthuma» (посмертное) и впоследствии «Senilia» (старческое). Этот небольшой по объему, но очень яркий и экспрессивный текст развивает одну из основных тем цикла - тему смерти. В.Н. Топоров в работе «Странный Тургенев» пишет, что «уже с 1857 года Тургенев стал думать о смерти и развивал эту думу в течение 26 лет... По действию неустанно работающего воображения, ему мерещились исключительные бедствия - он считал себя то укушенным бешеной собакой, то отравленным» (Топоров 2006: 38). Писатель и в этом последнем своем цикле много размышляет о смерти, он как бы переживает ее приближение, описывая различные аспекты - оттенки и нюансы переживания. У него нет иллюзий, что смерть можно избежать, потому что это не болезнь, от которой пусть даже чудом, но можно исцелиться, это неизбежное, а значит - необходимое. Тургенев так пристально смотрит, вглядывается в смерть, что подходит уже к любованию, к преследованию объекта - смерти.

Часть таких переживаний, «встреч» со смертью писатель переносит в пространство сна. Можно предположить, что ему это нужно для большей свободы в образной передаче самых сокровенных чувств и помыслов, чтобы не стеснять себя рамками реальности с ее неумолимой логикой и строгой детализацией. Но если заглянуть глубже в природу этой интенции, можно увидеть, что дело здесь не в рамках реального или в свободе от логики, но в стремлении прикоснуться к 
природе своего лирического переживания и в какой-то мере понять саму ситуацию страха смерти. «Стихотворения в прозе» — преимущественно лирические тексты, воспроизводящие глубоко личные, субъективные чувства.

По выражению Зигмунда Фрейда, «интерпретация сновидений является королевской дорогой к познанию бессознательных активностей психики» (Фрейд 2006: 78). А лирическое высказывание имеет интенцию поднять «на поверхность» самые глубокие пласты душевной (психической) жизни писателя, вплоть до тех, которые им могут не осознаваться в полной мере. Конечно, мы не предполагаем, что Тургенев явным образом избрал «королевскую дорогу» к познанию (и описанию) бессознательных активностей своей психики, но мы предполагаем, что его стремление «высказаться» с предельной откровенностью о своих самых сокровенных желаниях, тревогах, страхах и чаяниях оставило след в его лирических произведениях и этот след можно найти при помощи психоаналитического прочтения. С этой точки зрения становится понятным, почему Тургенев обращается к сновидению: сон, который рассказывают, - сон со значением, сон о чем-то свидетельствующий уже своим явлением (вещий сон), иначе говоря, сон, требующий интерпретации. Следует отметить, что первоначально Тургенев задумывал цикл из «стихотворений» под названием «CHbl», куда входили и рассматриваемые нами миниатюры.

У Тургенева в «Стихотворениях в прозе» ситуация встречи со смертью повторяется не единожды. Одна из миниатюр так и называется - «Встреча. Сон». Начинается она ровно с тех же слов, что и «Насекомое»: «Мне снилось...» Здесь образное описание встречи со смертью (сначала вглядывание в нее, а потом преследование) даже не метафорично, автор сам расшифровывает, интерпретирует сон: «Я начал вглядываться: облачко стало женщиной, стройной и высокой, в белом платье... Я непременно хотел догнать ее, хотел заглянуть в ее лицо...» (Тургенев 1982: 173). В конце концов лирический герой остается «неподвижен и нем на могильной моей плите» (Тургенев 1982: 173). Тут метафора уже не нужна — влечение к смерти, страстное желание заглянуть ей в лицо описано прямо и открыто.

В миниатюре «Насекомое» происходит столкновение влечения к смерти с желанием во что бы то ни стало ее избежать (с желанием, но не с действиями по избеганию ее). Рассмотрим подробнее, как происходит встреча со смертью в данном произведении.

«Снилось мне, что сидит нас человек двадцать в большой комнате с раскрытыми окнами.

Между нами женщины, дети, старики... Все мы говорим о каком-то очень известном предмете - говорим шумно и невнятно» (Тургенев 1982: 151).

Пространство сновидения сразу же дано как некомфортное, где собрались малознакомые люди для «невнятной» беседы. Особое значение здесь имеет то, кто собрался в комнате - представители обоих полов и всех возрастов: то есть, собственно, весь «мир» в одном месте, и это место распахнуто настежь, ничем не защищено - окна раскрыты.

«Вдруг в комнату с сухим треском влетело большое насекомое, вершка в два длиною... влетело, покружилось и село на стену. 
Оно походило на муху или на осу. Туловище грязно-бурого цвету; такого же цвету и плоские жесткие крылья; растопыренные мохнатые лапки да голова угловатая и крупная, как у коромыслов; и голова эта и лапки - ярко-красные, точно кровавые» (Тургенев 1982: 151).

Незащищенность, уязвимость тотчас разрешается вторжением страшного существа. Это его качество подчеркивается большим размером насекомого (около девяти сантиметров) и «точно кровавыми» головой и лапками.

«Странное это насекомое беспрестанно поворачивало голову вниз, вверх, вправо, влево, передвигало лапки... потом вдруг срывалось со стены, с треском летало по комнате - и опять садилось, опять жутко и противно шевелилось, не трогаясь с места.

Во всех нас оно возбуждало отвращение, страх, даже ужас... Никто из нас не видал ничего подобного, все кричали: «Гоните вон это чудовище!», все махали платками издали... ибо никто не решался подойти... и когда насекомое взлетало - все невольно сторонились» (Тургенев 1982: 151).

Насекомое странное (большое, шумное, беспокойное). Люди называют его чудовищем, машут на него платками, но боятся к нему приблизиться. Оно возбуждает отвращение и даже ужас, но ведет себя хоть и чрезвычайно нагло, но пока только как насекомое.

«Лишь один из наших собеседников, молодой еще, бледнолицый человек, оглядывал нас всех с недоумением. Он пожимал плечами, он улыбался, он решительно не мог понять, что с нами сталось и с чего мы так волнуемся? Сам он не видел никакого насекомого - не слышал зловещего треска его крыл» (Тургенев 1982: 151).

Тургенев описывает, как он вдруг увидел «особенного» человека - единственного из всех, кто не видел никакого насекомого. Но здесь есть один нюанс: автор - сновидец, это логика самого текста; весь сюжет, соответственно, рождается в его голове, но не в «дневном» сознании, а глубже - в бессознательном, и, следовательно, это он создает особенного молодого человека, который не видит насекомого, не слышит зловещего, предвещающего беду треска крыл.

«Вдруг насекомое словно уставилось на него, взвилось и, приникнув к его голове, ужалило его в лоб повыше глаз... Молодой человек слабо ахнул — и упал мертвым.

Страшная муха тотчас улетела... Мы только тогда догадались, что́ это была за гостья» (Тургенев 1982: 151).

Развязка наступает мгновенно: насекомое, также явившееся из глубины бессознательного сновидца, вслед за автором - как по его подсказке - увидело молодого человека и поразило его, ужалив в голову. Свершив свое черное дело, чудовище улетело, а все (здесь главное - что и сам сновидец) только тогда догадались, кто это был в образе насекомого (очевидно, что сама смерть).

Для интерпретации произведения достаточно указаний в самом тексте, но «Насекомое», как и любой текст, существует в контексте и других текстов, и фактов биографии автора, и многих других факторов, о которых писатель мо- 
жет даже не догадываться. Так, описание комнаты с распахнутыми окнами уже само по себе создает ощущение необустроенности и тревожного ожидания, и не столь важно, почему эти окна открыты настежь: в комнату может влететь что угодно. Насекомые часто вызывают отвращение и страх, особенно непомерно крупные и активные. Тургенев называет существо пять раз «насекомым», дважды «мухой», один раз говорит, что оно похоже на осу, один раз именует «чудовищем» и один раз «гостьей». Ни разу не называет «смертью», словно боясь произнести это слово, оставляя сделать это читателю. Но только ли страх произнести страшное слово «смерть» стал причиной подмены имени «гостьи»?

По Джорджу Тейлору, «все сны говорят на универсальном языке - языке метафоры и символа» (Тейлор 2000: 67). Прямая расшифровка символа лишает его части смысла: назвать насекомое «смертью» можно лишь в очень широком понимании, которое предполагает не только физическое прекращение жизни, но и исполнение рока или расплату за что-либо, свершение таинства, выпавший жребий, что-то еще и еще, и все это вместе. Только так можно передать гамму смыслов символа - через ряд других символов и метафор. То же и в художественном, особенно в лирическом произведении, использующим символическую образность: муха не то же самое, что оса. Оса проще - она может ужалить, может сделать больно, но муха - символ разложения и смерти, мухами повелевает демон Вельзевул. Муха вызывает отвращение. Но если она несет смерть, то значит, что она передает авторское отношение к смерти - отвращение. Таким образом, в «Насекомом» писатель противопоставляет влечению к смерти, которое он описал во «Встрече», инстинкт жизни. Более того - лирический герой «Насекомого» вместе со всеми в комнате испытывает страх перед агрессивным насекомым, предчувствуя, что оно несет опасность (смертельную, как оказалось), но этот страх и предчувствие опасности парадоксальным образом становятся спасением.

Обратимся к личным обстоятельствам писателя. Тургенев склонен к ипохондрии, что отмечалось многими авторами. Как свидетельствовала Н.А. Островская, «Тургенев часто объявлял, что он очень болен, и всегда воображал в себе какие-то необыкновенные болезни: то у него внутри головы, в затылке что-то сдирается, то точно какие-то вилки выталкивают ему глаза» (Топоров 1998: 38). Подобные его настроения усиливались с годами. А «Стихотворения в прозе» были написаны в конце жизни писателя и в них «слышатся интонации сожаления по поводу того, что старость должна сопровождаться болезнью и физическими страданиями - он воспринимал их именно как физические» (Беляева 2006: 39). И вот эту личностную черту, характерологическое свойство писатель, с одной стороны, снова транслирует в миниатюре «Насекомое»: страх смерти в образе отвратительной мухи врывается в комнату, где он находится, и всё заканчивается смертью; с другой же стороны, автор преодолевает этот страх, меняет по ходу сновидения сюжет и отводит от себя смерть: в комнате он не один, и погибает не он. Более того: его страх смерти служит ему защитой, писатель, как и все, боится мухи (боится смерти), он ясно видит ее, слышит отвратительный и зловещий треск ее крыл, но смерти нужен другой, тот, кто ее не видит и не слышит, тот, кто ее не боится. Автор - сновидец - создает этого человека, и сразу же смерть воззрилась на него, напала и убила. 
Так Тургенев «сотворил заклинание» от смерти и принес ей в жертву молодого человека, чтобы самому остаться в живых. Но не только. Писатель здесь еще и нарушил очевидную для него закономерность: смерть забирает старых. Будучи пожилым человеком с ипохондрическим складом характера, он был уверен, что ему скоро предстоит умереть, а значит, когда в комнату ворвалась муха, символизирующая смерть, она должна была забрать его или кого-нибудь из стариков, бывших с ним рядом. Но если бы смерть выбрала себе жертвой старика, то это выглядело бы случайностью или отсрочкой исполнения приговора - закона жизни, а не победой, пусть и иррациональной. «Сновидения пожилых людей проникнуты мотивами смерти, - пишет А.А. налчаджян, - размышлениями о ней, тревогой перед конечностью индивидуальной жизни человека, которая нередко достигает уровня страха и ужаса» (Налчаджян 2014: 127). Но если логика такова, что смерть забирает того, кто ее больше всего боится, то нужно или перестать бояться смерти, или, если это невозможно, следует изменить логику 一 и получается, что смерть забирает тех, кто ее не только не боится, но даже не замечает. Для этого, однако, подходит только логика сновидения. И именно эту форму выбрал Тургенев для своего стихотворения в прозе, где он высказал одно из самых своих сильных и сокровенных желаний - преодоление смерти.

\section{Использованная литература}

Беляева, Ирина А. Тема «старческого» у Тургенева и Шопенгауэра: К вопросу о «Стихотворениях в прозе». Спасский вестник Вып. 13. Тула: Гриф и К., 2006, 39-45.

[Belâeva, Irina A. Tema «starčeskogo» u Turgeneva i Šopengauèra: K voprosu o «Stihotvoreniâh v proze». Spasskij vestnik Vyp. 13. Tula: Grif i K., 2006, 39-45]

Налчаджян, Альберт А. Загадка смерти. Очерки психологической танатологии. Санкт-Петербург: Питер, 2014.

[Nalčadžân, Al'bert A. Zagadka smerti. Očerki psihologičeskoj tanatologii. SanktPeterburg: Piter, 2014]

Тейлор, Джордж. Работа со сновидениями: практическое руководство. Москва: Изд-во Института Психотерапии, 2000.

[Tejlor, Džordž. Rabota so snovideniâmi: praktičeskoe rukovodstvo. Moskva: Izd-vo Instituta Psihoterapii, 2000]

Топоров, Владимир Н. Странный Тургенев. Москва.: Изд-во РГГУ, 1998.

[Toporov, Vladimir N. Strannyj Turgenev. Moskva.: Izd-vo RGGU, 1998]

Фрейд, Зигмунд. Собрание сочинений в 10 томах. Т.2. Санкт-Петербург: ВЕИП, 2005.

[Frejd, Zigmund. Sobranie sočinenij v 10 tomah. T.2. Sankt-Peterburg: VEIP, 2005]

\section{Источники}

Тургенев, Иван С. Полн. собр. соч. и писем: В 30 т. Соч.: В 12 т. Т.10. Москва: Наука, 1982.

[Turgenev, Ivan S. Poln. sobr. soč. i pisem: V 30 t. Soč.: V 12 t. T.10. Moskva: Nauka, 1982] 


\section{Јелена Круглова}

\section{СИТУАЦИЈА СУСРЕТА СА СМРЋУ: ПСИХОАНАЛИТИЧКО ЧИТАЬЕ МИНИЈАТУРЕ И. С. ТУРГЕЬЕВА „ИНСЕКТ“ («НАСЕКОМОЕ»)}

\section{Резиме}

Психоаналитичка интерпретација текста уметничког дела је веома актуелна у светлу савремених интердисциплинарних проучавања. Психоаналитичко читање омогућује поглед на унутрашње, подсвесне мотиве аутора, који су недоступни оку биографа и књижевних критичара. Уметничка форма минијатуре као субјективног лирског исказа омогућује откривање веза између латентног смисла текста и суштине унутрашњег конфликта личности самог писца. Циклус «Стихова у прози» Тургењева, као његово последње дело, посебно је занимљиво jep се дотиче питања односа према смрти и рефлексивне анализе пређеног животног пута. Психоаналитички поглед на минијатуру Тургењева «Инсект» даје простора за претпоставку да се аутор не мири за неизбежном смрћу и налази начина да превлада сопствени страх.

Кључне речи: Иван Тургењев, Стихови у прози, смрт, страх, снови, психоанализа. 